\title{
Implementasi Kebijakan Penggunaan Sistem Keuangan Desa Di Kabupaten Sukabumi
}

\author{
${ }^{1}$ Khaerul Umam, ${ }^{2}$ Dedeng Maolani, ${ }^{3}$ Widi Maulana Rahman \\ ${ }^{1}$ Administrasi Publik Fakultas Ilmu Sosial dan Ilmu Politik UIN Sunan Gunung Djati Bandung; \\ umam@uinsgd.ac.id \\ ${ }^{2}$ Administrasi Publik Fakultas Ilmu Sosial dan Ilmu Politik UIN Sunan Gunung Djati Bandung; \\ dedeng@uinsgd.ac.id \\ ${ }^{3}$ Administrasi Publik Fakultas Ilmu Sosial dan Ilmu Politik UIN Sunan Gunung Djati Bandung; \\ widimr72@gmail.com
}

\begin{abstract}
The Cipeundeuy Village Government runs the Village Financial System, but the implementation still has several problems, including lack of facilities and infrastructure, lack of human resources and communication capabilities that are not going well. The purpose of this research is to find out how to implement the Village Financial System (SISKEUDES) Policy in Cipeundeuy Village. This study uses the theory of the implementation of Van Horn and Van Metter in Agustino (2014). The method used is descriptive qualitative. Data collection techniques used were interviews, observation, and documentation. Analysis of the data used is the Hubberman model in Mukhtar (2017). The results showed that the implementation of the use of siskeudes has not gone well. This can be seen from the lack of infrastructure, lack of human resources and communication capabilities that are not going well. Suggestions that can be given are the fulfillment of supporting facilities, there must be a shared desire to run the siskeudes and improve and strengthen communication patterns.
\end{abstract}

Keywords: Public Policy, Policy Implementation, Village, Financial System

\section{Pendahuluan}

Untuk membantu terwujudnya pelaksanaan pemerintah daerah yang mandiri atau sering kita sebut otonomi daerah sangat akan bergantung pada siap atau tidaknya pemerintah daerah dalam mengelola sistem pemerintahannya agar terwujudnya pembangunan yang efisien, efektif, akuntabel dan transparan dan juga mendapat partisipasi dari masyarakat di dalam penyelenggaraan pemerintahannya. Pemerintah pusat ingin mendongkrak mindset ini dengan dikeluarkannya Undang undang Selama ini desa dianggap sebagai tempat yang udik dan rendahan di banding kelurahan, sehingga tidak sedikit desa yang beralih menjadi kelurahan untuk mengangkat derajat sosial di mata masyarakat lainnya. Hal ini tentu tidak bisa membuat No. 6 Tahun 2014 tentang Desa yang terbaru yang mana desa merupakan daerah otonom dan berhak untuk mengatur dan mengelola desanya sendiri.

Sebagai pemerintah daerah yang memiliki otonomi daerah secara penuh, untuk melaksanakan pemerintahannya, maka pemerintah desa diharuskan untuk mencari mencari dana sendiri untuk mengembangkan desanya. Meski sekarang didalam Undangundang No. 6 Tahun 2014 menyatakan bahwa desa akan mendapatkan bantuan dari APBN setiap tahunnya sekitar 600 juta hingga 1,2 Milyar yang tercantum dalam UU No. 6 Tahun 2014 pasal 72 ayat (1) dan ayat (4) tentang desa, akan tetapi desa tidak sepenuhnya menggantungkan pendapatannya dari bantuan tersebut. Sesuai dengan amanat Undang-undang 
No.32 Tahun 2014 tentang Pemerintahan Daerah, yaitu dalam penyelenggaraan otonomi daerah dirasakan perlu agar menekankan pada prinsip-prinsip pemerintahan yang baik (Good Governance) dan pemerintahan yang bersih (Clean Governance) untuk mewujudkan pembangunan daerah yang desentralistik dan demokratis. Untuk mewujudkan prinsip-prinsip yang baik diperlukan sebuah pengelolaan keuangan yang akuntabel dan transparan dalam hal ini pemerintah mengeluarkan sebuah inovasi untuk mendukung asas akuntabel dan transparan melalui Peraturan Menteri Dalam Negeri (Permendagri) No. 113 Tahun 2014 tentang Pengelolaan Keuangan Desa, desa-desa di Indonesia mencari serta memanfaatkan aplikasi keuangan desa dari beraneka pengembang aplikasi (developer). Pada akhir 2015 lalu, Kemeterian Dalam Negeri bersepakat dengan BPKP untuk menyosialisasikan aplikasi besutan BPKP, yang diberi label SIMDA sebagai standar pelaporan APBDes. Dalam perkembangannya, SIMDA berrganti nama menjadi Siskeudes dan mulai diperkenalkann ke desa-desa di Indonesia.Adanya Siskuedes merupakan langkah baru pemerintah untuk menghadapi kemajuan teknologi dan mencoba menutupi celah yang selama ini sering terjadi pelanggaran dan penyimpangan dalam pelaporan keuangan. Sehingga penerapan Siskeudes ini menjadi solusi yang ditawarkan untuk selangkah lebih maju dalam menerapkan asas-asas pemerintahan yang baik (Good Governance).

Penerapan Siskeudes di Kabupaten Sukabumi mulai diterapkan pada tahun 2016 namun pada saat itu hanya tiga Desa yang sudah berjalan yaitu Desa Karang Papak, Desa Bojong Kaler, dan Desa Citanglar. Pada tahun 2017 penerapan Siskeudes di Kabupaten Sukabumi sudah menyentuh angka 70\% namun ada beberapa Desa yang masih perlu bimbingan dalam melaksanakan Siskeudes ini, Di Kecamatan Surade itu sendiri Desa yang baru melaksanakan siskeudes sekitar 50\%. Pada tahun 2018 di Kecamatan Surade Siskuedes sudah hampir berjalan sepenuhnya yaitu sekitar 90\% namun ada beberapa Desa yang masih belum berjalan yaitu Desa Sirnasari, Desa Cipeundeuy, dan Desa Warnasari.

Sebagai salah satu Kecamatan yang berada di daerah pelosok, Kecamatan Surade membutuhkan perhatian khusus, perhatian dalam pengawasan maupun dari segi bimbingan. Sebagian desa yang ada dalam ruang lingkup Kecamatan Surade memiliki masalah yang sama dalam pengawasan dan bimbingan maka dari itu penerapan Siskeudes menjadi tantangan yang sulit bagi beberapa desa. Masih ada beberapa desa dalam ruang lingkup Kecamatan Surade yang masih terkendala dalam penerapan Siskeudes ini, bahkan ada beberapa desa yang belum bisa menerapkan sama sekali dan beberapa masih dalam tahap bimbingan Desa lain.

Model pendekatan top-down yang dirumuskan oleh Van Metter dan Van Horn dalam (Agustino, 2014) disebut dengan A Model of The Policy Implementation. Proses implementasi ini merupakan sebuah abstraksi atau performansi suatu implementasi kebijakan yang pada dasarnya secara sengaja dilakukan untuk meraih kinerja implementasi kebijakan publik yang tinggi yang berlangsung dalam hubungan berbagai variabel. Model ini mengandalkan bahwa implementasi kebijakan berjalan secara linier dari keputusan politik yang tersedia, pelaksana, dan kinerja kebijakan publik. 
Ada enam variabel, menurut Van Metter dan Van Horn, yang mempengaruhi kinerja kebijakan publik tersebut adalah:

1) Ukuran dan Tujuan Kebijakan

2) Sumber Daya

3) Karakteristik Agen Pelaksana

4) Sikap/Kecenderungan (Disposition) para Pelaksana

5) Komunikasi Antarorganisasi dan Aktivitas Pelaksana

6) Lingkungan Ekonomi, Sosial, dan Politik.

Sesuai dengan latar belakang penelitian di atas yang telah dipaparkan, maka tujuan dari penelitian ini adalah untuk mengetahui bagaimana Implementasi Kebijakan Penggunaan Sistem Keuangan Desa (Siskeudes) di Desa Cipeundeuy.

\section{Metode Penelitian}

Penelitian ini menggunakan pendekatan kualitatif dengan bentuk penelitian deskriptif. Metode deskriptif kualitatif ini digunakan karena beberapa pertimbangan, yaitu bahwa penelitian ini ingin menggambarkan permasalahan sosial sebenarnya yang terjadi di lapangan dan berusaha untuk menganalisis permasalahan sosial tersebut sesuai dengan pertanyaan penelitian. Penelitian ini ingin memberikan gambaran mengenai implementasi kebijakan pengguunaan system keuangan desa di Kabupaten Sukabumi. Jenis data yang digunakan dalam penelitian ini adalah data kualitatif. Data kualitatif merupakan sumber dari deskripsi yang luas, dimana pengumpulan data dipandu oleh fakta-fakta yang ditemukan pada saat penelitian dilapangan. Oleh karena itu, analisis data yang dilakukan pun berdasarkan faktafakta yang ditemukan. Sumber data yang digunakan dalam penelitian ini berupa data primer dan data sekunder. Dalam rangka mengumpulkan data-data penelitian, penulis melakukan wawancara mendalam kepada beberapa informan yang terkait serta studi dokumentasi. Sedangkan dalam melakukan analisis data, Peneliti menggunakan model Miles dan Huberman (2007) tentang analisis data yang terdiri dari beberapa langkah yaitu, reduksi data, data display atau penyajian, penarikan kesimpulan/ verifikasi.

\section{Hasil Dan Pembahasan}

Deskripsi hasil penelitian ini merupakan suatu data dan fakta yang peneliti dapatkan langsung dari lapangan serta disesuaikan dengan teori yang peneliti gunakan yaitu menggunakan teori implementasi kebijakan menurut Van Metter dan Van Horn dalam Agustino (2014). Dalam teori tersebut, proses implementasi ini merupakan sebuah abstraksi atau performansi suatu implementasi kebijakan yang pada dasarnya secara sengaja dilakukan untuk meraih kinerja implementasi kebijakan publik yang tinggi yang berlangsung dalam hubungan berbagai variable. Model ini mengandaikan bahwa implementasi kebijakan berjalan secara linier dari keputusan politik yang tersedia, pelaksana, dan kinerja kebijakan publik.

\section{Ukuran dan Tujuan Kebijakan}

Pelaksanaan kebijakan tidak terlepas dari sebuah peraturan sebagai landasan pelaksana kebijakan. Suatu implementasi kebijakan dapat diukur tingkat keberhasilannya jika ukuran dan tujuan dari kebijakan memang realistis dan sesuai dengan sosio kultur yang berada di level pelaksana kebijakan dan pengawas kebijakan. Melaksanakan siskuedes disuatu desa tentu tidaklah mudah terlebih lagi dilaksanakan di suatu daerah yang masih pelosok seperti Desa Cipeundeuy yang berada di selatan Kabupaten Sukabumi. Meski dari tahun 2015 Menteri 
Dalam Negeri kala itu membuat regulasi kebijakan mengenai siskeudes, namun nyatanya siskeudes ini belum bisa terealisasi di seluruh desa di Indonesia. Contohnya di Desa Cipeundeuy itu sendiri, berdasarkan hasil wawancara dengan Bapak Suhenda, sebagai Sekretaris Desa Cipeundeuy, yang menyebutkan bahwa:

"Sulit, karena terbatasnya sumber daya manusia dan sarana prasarana yang kurang memadai sehingga mengakibatkan terhambatnya pelaksanaan siskeudes di Desa Cipeundeuy." (7 Februari 2019, Pukul 09.00 WIB, di Kantor Desa Cipeundeuy).

Berdasarkan wawancara diatas bisa disimpulkan bahwa pelaksanaan kebijakan penggunaan siskeudes masih sulit dilaksanakan di Desa Cipeundeuy, hal tersebut diakibatkan karena terbatasnya kemampuan yang dimiliki oleh pegawai dan kurang tersedianya sarana dan prasarana yang mumpuni. Hal tersebut juga diperkuat oleh pendapat dari pak Ade Gusti sebagai Bendahara Desa Ciepeundeuy atau Kaur Keuangan yang melalui sebuah wawancara yang disampaikan sebagai berikut.

"Seperti yang telah disampaikan tadi Desa Cipeundeuy memiliki keterbatasan baik dalam sumber daya manusia maupun sarana prasarana yang menunjang." (7 Februari 2019, Pukul 10.00 WIB, di Kantor Desa Cipeundeuy).

Berdasarkan wawancara diatas dapat dipastikan bahwa memang pelaksanaan siskeudes di Desa Cipeundeuy memang sulit untuk diterapkan. Tujuan dari adanya siskeudes yaitu untuk memudahkan dalam proses keuangan yang ada di desa serta agar keuangan di desa lebih transparan dan akuntabel. Kesesuaian tujuan yang dimiliki desa akan menjadi pendorong pelaksaan siskeudes. Seperti yang dinyatakan oleh Kepala Desa Cipeundeuy sebagai berikut.

"99\% siskeudes sesuai dengan tujuan Desa Cipeundeuy. Namun 1\% tidak sesuai karena Desa Cipeundeuy berada di perkampungan.” (14 Februari 2019, Pukul 14.30 WIB, di Kantor Desa Cipeundeuy).

Hal ini juga senada dengan yang disampaikan oleh Sekretaris Kecamatan Surade yang menerangkan secara lebih meluas mengenai keselarasan antara tujuan siskeudes dengan tujuan Kecamatan Surade sebagai berikut.

"Siskeudes merupakan sebuah inovasi dalam pengelolaan keuangan desa. Siskeudes sangat membantu desa dalam pengeloaan keuangan di desa sehingga pengelolaan keuangan di desa bisa berjalan dengan efektif dan efisien. Selain itu dapat mengurangi celah-celah dalam penyalahgunaan keuangan yang berasal dari pusat maupun provinsi seperti apa yang telah dicita-citakan masyarakat mewujudkan desa yang akuntabel." (11 Februari 2019, Pukul 13.30 WIB, di Kantor Kecamatan Surade).

Berdasarkan hasil wawancara diatas menunjukan bahwa pihak kecamatan menyambut baik adanaya siskedeus ini karena kebijakan siskeudes merupakan sebuah inovasi yang sangat baik karena selain membuat pengeloaan keuang di desa menjadi efektif dan efisien siskeudes juga dapat mencegah adanya penyalahgunaan dari perencanaan sampai kepada pelaksanaan, bahkan beliau menambahkan bahwa ini bukan hanya menjadi keinginan dan harapan dari kecamatan tetapi juga merupakan harapan dari masyarakat desa. 


\section{Sumber Daya}

Sumber daya sangat berperan penting dalam pelaksanaan suatu kebijakan. Implementasi kebijakan perlu dukungan sumber daya baik sumber daya manusia (maupun sumbe daya non manusia. Pertama adalah sumberdaya manusia, dalam proses pelaksanaan siskeudes di Desa Cipeundeuy unsur sumber daya manusia yang paling berperan adalah sekretaris desa, karena sekretaris desa lah yang menjalankan dan melaksanakan siskeudes. Seperti yang sudah disinggung diatas bahwa Desa Cipeundeuy memilik beberapa masalah mengenai pelaksanaan siskeudes salah satunya sumber daya manusia. Hal ini disebutkan oleh pendamping desa melalui sebuah wawancara sebagai berikut.

"Siskeudes sulit dikarenakan karena perangkat desa kurang memiliki keinginan untuk belajar padahal mereka memiliki potensi untuk mengerjakan bahkan kadang juga dikerjakan oleh orang lain." (8 Februari 2019, Pukul 09.30 WIB, di Kantor Desa Cipeundeuy).

Dilihat dari hasil wawancara diatas bisa disimpulkan bahwa memang sumber daya manusia di Desa Cipeundeuy memiliki sebuah permasalahan yang menghambat pelaksanaan siskeudes tadi, watak dari pelaksana yang tidak mau belajar menjadi benalu yang membuat siskeudes tidak dapat berjalan dan cenderung mengandalkan orang lain. Hal ini juga disampaikan oleh sekretaris kecamatan mengenai sumber daya manusia yang ada di desa-desa wilayah Kecamatan Surade sebagai berikut.

"Tidak terlalu sulit karena rata-rata perangkat desa yang berada di wilayah Kecamatan Surade memiliki pengetahuan dan pemahaman di bidang teknologi dan informasi, tinggal sejauh mana perangkat desa mau mempelajari siskeudes tersebut." (11 Februari 2019, Pukul 13.30 WIB, di Kantor Kecamatan Surade).

Dari hasil wawancara diatas dapat disimpulkan bahwa dari segi pemahaman informasi dan teknologi khususnya sistem komputerisasi secara umum memang para perangkat desa ini sudah cukup mumpuni tapi hal tersebut dikembalikan lagi kepada sejauh mana perangkat desa tersebut mau mempelajari dan mendalami mengenai siskeudes.

Kedua adalah sumber daya finansial, terkait sumber daya finansial tidak terlepas dari anggaran baik itu APBD maupun APBN. Sesuai dengan UU Desa No. 6 Tahun 2014, desa mendapat dana dari APBN sekitar 600 juta hingga 1,2 Miliyar untuk setiap tahunnya. Maka dari itu setiap desa akan menerima dana sedemikian banyak dari pemerintah pusat secara Cuma-Cuma yang harus dikelola oleh desa. Hal ini tentu sangat mendukung untuk penyedian sarana-prasarana untuk pemenuhan sarana yang dibutuhkan oleh desa untuk melaksanakan kebijakan siskeudes.

Hal ini juga di dukung oleh pernyataan kepala desa mengenai kecukupan finansial untuk mendukung pelaksanaan siskeudes sebagai berikut "Anggaran untuk melaksanakan siskeudes cukup, namun apabila untuk pelaksanaan dilapangan anggaran masih kurang." (Wawancara dengan bapak Kuswandi, 14 Februari 2019, Pukul 14.30 WIB, Di Kantor Desa Cipeundeuy). 
Berdasarkan hasil wawancara diatas dapat disimpulkan bahwa anggaran atau finansial yang dimiliki oleh Desa Cipeundeuy mencukupi untuk melaksanakan kebijakan siskuedes di Desa Cipeundeuy Selain dari pihak desa pihak kecamatan juga memberikan intruksi kepada desa-desa yang ada di wilayah Kecamatan Surade agar menyediakan anggaran untuk melaksanakan siskeudes sebagai berikut.

"Dalam setiap penyusunan anggaran kami selalu mendorong agar desa dapat berjalan dengan baik, kami juga mengintruksikan agar kebijakan siskeudes menjadi prioritas agar kelengkapan sarana dan prasarana segera dipenuhi khususnya internet." (11 Februari 2019, Pukul 13.30 WIB, di Kantor Kecamatan Surade).

Melalui pernyataan tersebut dapat dilihat bahwa pihak kecamatan pun mendukung dan memberikan intruksi kepada tiap-tiap desa khusunya desa yang memiliki sarana dan prasarana yang cukup untuk melaksanakan siskeudes.

Ketiga adalah sumber daya waktu, sumber daya waktu ini memfokuskan kepada apakah waktu yang dipergunakan untuk melaksanakan sebuah kebijakan itu cukup karena seperti yang telah disampaikan diatas bahwa waktu pun memiliki andil besar terhadap terlaksananya sebuah kebijakan khusussnya dalam hal ini implementasi kebijakan penggunaan sistem keuangan desa (SISKEUDES). Seperti apa yang dikemukakan oleh sekretaris kecamatan sebagai berikut.

"Tidak dipungkiri bahwa kebijakan siskeudes ini memang kebijakan yang masih baru namun disi lain desa harus segera terintegrasi siskeudes sehingga pemberian pengetahuan masih kurang, sehingga harus terus diberikan pemahaman sambal berjalan" (11 Februari 2019, Pukul 13.30 di Kantor Kecamatan Surade).

Berdasarkan hasil wawancara diatas dapat disimpulkan bahwa memang waktu yang diperlukan bagi desa-desa untuk mempelajari siskeudes ini terlalu singkat karena yang menjadi kendala dalam penerapan nya itu pemerintah pusat cenderung terburuburu untuk menerapkan siskeudes sehingga penerapan siskeudes kurang optimal karena sumber daya manusia yang belum siap. Senada dengan itu kepala desa cipeundeuy pun memberikan pernyataan yang sama mengenai hal tersebut.

"Waktu yang diberikan untuk mempelajari siskeudes tidak cukup karena Sukabumi adalah Kabupaten terluas se Jawa dan Bali. Namun kami berusaha mendorong perangkat desa yang ada agar dapat mempelajari dengan maksimal serta terus berkoordinasi dengan BPMD.”. (14 Februari 2019, Pukul 14.30 WIB, di Kantor Desa Cipeundeuy).

Berdasarkan wawancara diatas dapat dilihat bahwa memang waktu yang dibutuhkan untuk mempelajari siskeudes ini memang tidak cukup dengan alasan Kabupaten Sukabumi merupakan kabupaten terluas sejawa bali sehingga koordinasi menjadi sedikit terhambat.

Ketiga sumber daya tersebut saling berkaitan antara sumber daya manusia, sumber daya finansial dan sumber daya waktu. Sumber daya manusia dalam pelaksanaan siskeudes di desa Cipeundeuy ini memiliki kekurangan dalam hal segi pembelajaran aparat atau pegawai desa Cipeundeuy itu sendiri kurang memiliki 
keinginan untuk belajar dan cenderung mengandalkan orang lain. Sedangkan dalam sumber daya finansial sangat cukup untuk melaksanakan siskeudes ini khusunya penganggaran untuk melengkapi sarana dan prasarana untuk melaksanakan siskeudes dan waktu yang dibutuhkan untuk mempelajari siskeudes ini tidak cukup.

\section{Karakteristik Agen Pelaksana}

Agen pelaksana ikut menjadi salah satu hal yang harus diperhatikan dalaam sebuah implementasi. Dalam salah satu indikator teori Van Metter dan Van Horn ini pusat perhatian pada agen pelaksana meliputi organisasi formal dan organisasi informal yang akan terlibat pengimplementasian kebijakan public. Hal ini sangat penting karena kinerja implementasi kebijakan publik akan sangat banyak dipengaruhi oleh ciri-ciri yang tepat serta cocok dengan para agen pelaksananya. Misalnya, implementasi kebijakan publik yang berusaha untuk merubah prilaku atau tindak laku manusia secara radikal, maka agen pelaksana projek itu haruslah berkarakterisitik keras dan ketat pada aturan serta sanksi hukum. Serta apabila kebijakan publik itu tidak terlalu merubah prilaku dasar manusia, maka dapat saja agen pelaksana yang diturunkan tidak sekeras dan tidak setegas pada gambaran yang pertama.

Dilihat dari pengertian diatas bahwa untuk melaksanakan kebijakan siskeudes di suatu desa bukanlah suatu yang mudah apalagi diterapkan di daerah-daerah pelosok yang bisa dikatakan masih daerah tertinggal. Pemikiran dan pemahaman yang masih tradisional menjadikan aparatur pemerintah berada di zona nyaman dan sulit untuk menerima sebuah perubahan seperti apa yang disampaikan oleh Sekretaris Desa sebagai berikut.

"karena kebanyakan pegawai sudah dalam usia tidak produktif maka kemauan untuk belajar dan menerima hal-hal baru itu kurang." (7 Februari 2019, Pukul 09.00 WIB, di Kantor Desa Cipeundeuy).

Berdasarkan wawancara diatas dapat dilihat bahwa memang mindset para aparatur pemerintahh desa berada di usia yang tidak produktif dan sulit menerima akan hal-hal baru. Meski mindset bukan menjadi hambatan utama dalam menjalankan siskeudes di Desa Cipeundeuy namun apabila para aparaturnya tidak memiliki keinginan untuk mempelajari dan melaksanakan nya, pelaksanaan siskeudes tidak akan terwujud. Seperti apa yang dikatakan oleh Pendamping Desa Cipeundeuy sebagai berikut.

\section{"Tidak ada hambatan semua menerima kebijakan tersebut cuman seperti yang tadi dikatakan bahwa hambatannya karena tidak mau tekun belajar siskeudes." ( 8 Ferbruari 2019, Pukul 09.30 WIB di Kantor Desa Cipeundeuy).}

Berdasarkan wawancara diatas dapat disimpulkan bahwa kendala yang dihadapi oleh Pemerintah Desa Cipeundeuy dalam menjalankan siskeudes adalah individualnya. Hal ini dikarenakan para pelaksana siskeudes tidak mau mempelajari dan mendalami tentang siskeudes sehingga pelaksanaan siskeudes menjadi terhambat.

\section{Sikap/Kecenderungan (Disposition) Para Pelaksana}

Keberhasilan atau tidaknya kinerja implementasi kebijakan publik akan ditentukan dengan sikap penerimaan atau penolakan dari (agen) pelaksana. Maka dari itu sangat mungkin terjadi oleh karena kebijakan yang dilaksanakan bukanlah hasil formulasi warga setempat yang mengenal betul persoalan dan permasalahan yang 
mereka rasakan. Tetapi kebijakan yang akan dilaksanakan implementor adalah kebijakan "dari atas" (Top Down) yang sangat mungkin para pengambil keputusannya tidak pernah mengetahui bahkan tidak mampu menyentuh kebutuhan, keinginan, atau permasalahan yang warga ingin selesaikan. Sikap penerimaan dalam pelaksanaan kebijakan siskeides degan ikut menjalankan siskeudes tersebut, mulai melengkapi sarana dan prasarana yang belum ada dan terus berkoordinasi dengan desa lain. Seperti yang disampaikan oleh Sekretaris Desa Cipeundeuy sebagai berikut.

\section{"Melengkapi sarana dan prasarana dengan merencanakan dalam anggaran yang akan datang serta tetap berkoordinasi dengan desa lain.". (7 Februari 2019, Pukul 09.00 WIB, Di Kantor Desa Cipeundeuy).}

Berdasarkan wawancara diatas dapat disimpulkan bahwa pemerintah desa menerima kebijakan siskeudes serta mendukung pelaksanaan siskeudes ini dengan terus berkoordinasi dengan desa lain khususnya yang lebih dulu bisa melaksanakan siskeudes selain itu pemerintah Desa Cipeundeuy juga berusaha untuk memenuhi kebutuhan sarana dan prasrana yang dibutuhkan untuk melaksanakan siskeudes. Selain itu tidak ada penolakan sedikitpun dari pemerintah Desa Cipeundeuy untuk melaksanakan siskeudes seperti apa yang disampaikan oleh Sekretaris Desa Cipeundeuy sebagai berikut

"Sejauh ini tidak ada indikasi penolakan dari pihak manapun termasuk dari pihak pemerintah desa Cipeundeuy itu sendiri" (7 Februari 2019, Pukul 09.00 WIB, Di Kantor Desa Cipeundeuy).

Berdasarkan wawancara diatas dapat dilihat bahwa pemerintah Desa Cipeundeuy tidak menolak dengan adanya siskeudes ini dan bahkan mendukung pelaksanaan siskeudes dengan melaksanakan siskeudes dan menganggarkan untuk melengkapi sarana dan prasaran yang belum tersedia untuk menopang terwujudnya siskeudes.

\section{Komunikasi Antarorganisasi dan Aktivitas Pelaksana}

Manusia sebagai pelaku kebijakan akan butuh komunikasi dalam menjalankan suatu kebijakan. Komunikasi atau sering juga disebut koordinasi di intansi pemerintah merupakan mekanisme yang ampuh dalam implementasi kebijakan publik. Semakin baik koordinasi komunikasi diantara pihak-pihak yang terlibat dalam suatu proses implementasi, maka asumsinya kesalahan-kesalahan akan sangat kecil untuk terjadi. Dan begitu pula sebaliknya, dalam pelaksanaan kebijakan siskeudes koordinasi merupakan peran penting dari setiap pihak yang terkait dengan kebijakan tersebut.

Koordinasi sangat dibutuhkan agar pelaksanaan siskeudes dapat berjalan, in agar tidak ada tumpeng tindih tugas dari masing-masing stakeholder sehingga tugas pokok dan fungsi dari tiap pihak yang terkait harus sudah memahami. Namun di Desa Cipeundeuy itu sendiri memiliki beberapa permasalahan dalam komunikasi seperti komunikasi yang antara atasan dengan bawahan seperti yang dikatan oleh sekretaris desa sebagai berikut.

"Komunikasi yang terjalin antara kepala desa dengan para staf berjalan kurang baik karena kepala desa jarang berada di kantor."

(7 Februari 2019, Pukul 09.00 WIB, Di Kantor desa Cipeundeuy). 
Berdasarkan wawancara diatas dapat dilihat bahwa komunikasi yang terjalin antara kepala desa dengan bawahan itu kurang berjalan dengan lancar sehingga komunikasi yang terjalin terganggu selain itu kepala desa juga jarang masuk kantor karena alasan yang tidak jelas.

Selain itu Sekretaris Desa selaku pelaksana kebijakan tidak memiliki komunikasi yang lencar dengan para staf lain khususnya dalam pelaksanaan kebijakan siskeudes ini seperti apa yang dikatakan oleh Pendamping Desa sebagai berikut:

"Sebagai bentuk dukungan saya sering memberikan masukan kepada sekdes apabila tidak mau untuk mendalami siskeudes agar mencari staf lain yang benar-benar dapat diandalkan untuk menjalankan siskeudes" (8 Februari 2019, Pukul 09.30 WIB, Di Kantor Desa Cipeundeuy).

Bisa kita lihat dari wawancara diatas Sekretaris Desa tidak mau berkoordinasi dengan staf lain dalam menjalankan siskeudes padahal Sekretaris Desa tersebut tidak mampu untuk melaksanakan kebijakan siskeudes tersebut. Selain daripada itu komunikasi yang terjalin antara Desa Cipeundeuy dengan desa-desa lain yang lebih dulu bisa menjalankan siskeudes berjalan lancar seperti yang dikatakan oleh Kepala Desa sebagai berikut.

"Pasti karena sekarang sudah ada grup online antar perangkat desa yang mempermudah perangkat desa untuk berkoordinasi." (14 Februari 2019, Pukul 14.30 WIB, Di Kantor Desa Cipeundeuy).

Dilihat dari wawancara diatas dapat kita lihat walaupun Desa Cipeundeuy memiliki permasalahan dalam komunikasi internal dalam desa namun Desa Cipeundeuy memiliki komunikasi yang baik dengan desa lain khususnya dalam hal kebijakan siskeudes hal ini di dukung oleh adanya grup sekdes yang memudahkan untuk saling berkomunikasi.

\section{Lingkungan Ekonomi, Sosial, dan Politik}

Hal terakhir yang perlu juga diperhatikan adalah sejauh mana lingkungan eksternal turut mendorong keberhasilan kebijakan publik yang telah ditetapkan. Lingkungan sosial, ekonomi, dan politik yang tidak kondusif dapat menjadi biang keladi dari kegagalan kinerja impelementasi kebijakan. Karena itu, upaya untuk mengimplementasikan kebijakan harus pula memperhatikan kekondusifan kondisi lingkungan eksternal.

Jika dilihat dari lingkungan ekonomi dalam implementasi kebijakan siskeudes secara umum sudah cukup kondusif. Walaupun tingkat perekonomian bisa dikatakan kurang baik karena jauhnya akses ke kota dan pusat perbelanjaan menjadikan pertumbuhan ekonomi cukup lambat. Namun lingkungan perekonomian tidak terlalu berpengaruh dengan kebijakan siskeudes itu seperti yang disampaikan oleh Sekretaris Desa sebagai berikut

"Tidak ada pengaruhnya dikarenakan kebijakan siskeudes murni dibiayai oleh pemerintah pusat dan daerah." (7 Februari 2019, Pukul 09.00, Di Kantor Desa Cipeundeuy).

Melalui wawancara diatas dapat dilihat bahwa ekonomi eksternal tidak memiliki pengaruh terhadap kebijakan siskeudes bahkan ekonomi yang didapatkan dari Pendapatan Asli Desa (PAD) tidak memiliki pengaruh karena itu murni anggaran yang berikan oleh pusat. Lingkungan politik juga yang tidak terlepas dari pemerintahan baik 
di daerah maupun di desa cukup mendukung jalannya siskeudes ini dengan adannya beberapa kali diadakan program bimtek yang dilaksanakan oleh pemerintah daerah.Lingkungan sosial masyarakat Desa Cipeundeuy cenderung acuh dengan pelaksanaan pemerintahan yang ada di Desa Cipeundeuy tentu saja perihal siskeudes juga sama, apalagi siskeudes merupakan kebijakan yang tidak bersentuhan langsung dengan masyarakat luas sehingga pengetahuan masyarakat mengenai siskeudes sangat tertutup.

Selain itu, terdapat enam variabel, menurut Van Meter dan Van Horn, yang mempengaruhi kinerja kebijakan publik tersebut (Agustino, 2014), yaitu: mengenai ukuran dan tujuan kebijakan, sumber daya, karakteristik agen pelaksana, sikap/kecenderungan para pelaksana, komunikasi antarorganisasi dan aktivitas pelaksana, dan yang terakhir lingkungan ekonomi, social dan politik. Berikut ini peneliti akan membahas lebih lanjut terkait analisis hasil penelitian.

Pertama, ukuran dan tujuan kebijakan. Peneliti melihat bahwa pelaksanan siskeudes di Desa Cipeundeuy kurang berjalan diakibatkan selain karena keadaan Desa Cipeundeuy yang berada di daerah pelosok yang memang untuk melaksanakan kebijakan siskeudes masih sulit diakibatkan karena sulitnya menerima sebuah perubahan dan inovasi baru. Selain daripada itu para pegawai tidak memiliki keinginan untuk mempelajari siskeudes tersebut, selain itu kelengkapan sarana dan prasarana yang menunjang pelaksanaan siskeudes belum tersedia apalagi dalam hal ini belum ada jaringan internet yang memadai untuk melaksanakan siskeudes. Disamping itu, tujuan dibuatnya aplikasi siskeudes ini selain sebagai bentuk kepedulian pemerintah pusat untuk melaksanakan pemerintahan desa yang baik khususnya dalam hal pengelolaan keuangan yanga transparan dan akuntabel, selain dari itu siskeudes juga mempermudah pelaksaan pengelolaan keuangan di desa karena adanya perubahan basis pelaporan manual ke pelaporan berbasis computer. Berdasarkan tujuan ini, pelaksanaan siskeudes di Desa Cipeundeuy belum mampu mencapai ekspetasi dari pemerintah pusat karena masih terhambat sumber daya manusia dan fasilitas yang ada.

Kedua, sumberdaya yang terdiri dari sumberdaya manusia (human reosources) dan sumberdaya non manusia (non human resources). Kondisi sumber daya manusia dalam pelaksanaan siskeudes di Desa Cipeundeuy ini adalah sekretaris desa. Sehingga apabila sumber daya manusia atau sekretaris desa ini tidak memahami siskeudes maka pelaksanaan siskeudes di Desa Cipeundeuy akan terhambat. Sangat disayangkan bahwa perangkat desa yang sudah jelas digaji pemerintah seharusnya memiliki kemampuan yang cukup untuk melaksanakan sebuah kebijakan khususnya dalam hal ini kebijakan siskeudes agar supaya pelaksanaan pemerintah yang baik (good governance) dapat diwujudkan. Sedangkan sumberdaya finansial sangat berkaitan dengan sumber daya waktu. Terkait sumber daya finansial, dana yang dipakai untuk melaksanakan siskeudes khususnya dalam segi melengkapi sarana dan prasarana yang mendukung sebagian besar merupakan dana bantuan dari pemerintah, waktu yang dibutuhkan untuk mempelajari siskeudes ini kurang cukup untuk pemerintah Desa Cipeundeuy karena beberapa alasan seperti belum adanya pemenuhan kebutuhan sumber daya manusia dan fasilitas yang memadai.

Ketiga, karakteristik agen pelaksana dalam pelaksanaan kebijakan siskeudes haruslah sinkron satu sama lain, nahwa pelaksanaan siskeudes di Desa Cipeundeuy banyak hambatan yang telah dilewati diantaranya adalah kurangnya kualitas sumber daya manusia dan kurangnya fasilitas dalam hal ini jaringan internet. Kurangnya 
sumber daya manusia yang ada memiliki kemampuan yang minim untuk melaksanakan siskeudes dan sifatnya yang malas untuk belajar, mengapa demikian karena pemerintah telah sering melakukan BIMTEK mengenai siskeudes namun tetap saja tidak bisa melaksanakan siskeudes.

Keempat, sikap/kecenderungan (disposition) para pelaksana. Sikap penerimaaan atau penolakan dari (agen) pelaksana akan sangat banyak mempengaruhi keberhasilan atau tidaknya kinerja implementasi kebijakan publik. Maka dalam penelitian ini, sikap yang ditampilkan adalah sikap penerimaan dari berkaitan dengan pelaksanaan kebijakan siskeudes. Pemerintah Desa Cipeundeuy dalam hal ini mendukung pelaksanaan kebijakan siskeudes bahkan sebagai bentuk dukungannya pemerintah Desa Cipeundeuy mencoba melengkapi fasilitas yang mendukung pelaksanaan kebijakan siskeudes.

Kelima, yaitu komunikasi antarorganisasi dan aktivitas pelaksana. Dalam pelaksanaan kebijakan siskeudes, koordinasi berperan sangat penting. Karena, kebijakan siskeudes merupakan kebijakan dari pemerintah pusat yang dilaksanakan oleh pemerintah desa dengan melibatkan semua elemen dalam hal ini pemerintah desa dan DPMD. Koordinasi dan komunikasi yang dilakukan oleh pemerintah Desa Cipeundeuy dilakukan sesuai dengan kebutuhan baik itu komunikasi dengan DPMD maupun dengan desa-desa lain yang sudah bisa melaksanakan kebijakan siskeudes sepenuhnya. Kordinasi yang terjalin berjalan lancar dengan memanfaat kan kemajuan jaman yaitu melalui grup-grup di media sosial sehingga untuk berkoordinasi khususnya dalam hal kebijakan siskeudes. Sedangkan koordinasi dan komunikasi yang dilakukan di dalam pemerintahan Desa Cipeundeuy kurang berjalan dengan baik khususnya dalam hal ini komunikasi yang terjalin antara atasan dengan bawahan, hal ini dikarenakan kepala desa selaku atasan tertinggi jarang memasuki kantor kepala desa sehingga tidak memberikan intruksi ataupun pengawasan kepada pelaksana siskeudes, sehingga kepala desa cenderung untuk acuh terhadap kebijakan siskeudes ini dan diserahkan sepenuhnya kepada sekretaris desa selaku pelaksana kebijakan siskeudes.

Keenam, yaitu lingkungan ekonomi, sosial, dan politik. Jika dilihat dari lingkungan ekonomi yang ada di di lingkungan Desa Cipeundeuy pada saat sebelum dilaksanakan siskeudes mayoritas mata pencaharian adalah petani dengan lingkungan pedesaan yang hijai sebagai lahan pertanian mereka. Meski memiliki kehidupan yang sederhana namun keasrian lingkungan membuat masyarakat betah tinggal di desanya sendiri. Lingkungan politik juga yang tidak terlepas dari pemerintahan baik daerah maupun di desa cukup mendukung jalannya kebijakan siskeudes ini, program bimbingan teknis sering dilakukan oleh pemerintah pusat maupun pemerintah daerah cukup membantu jalannya siskeudes di Desa Cipeundeuy ini. Lingkungan sosial masyarakat Desa Cipeundeuy tidak memiliki pengaruh yang signifikan terhadap kebijakan siskeudes karena kebijakan ini merupakan kebijakan di tingkat internal desa dan tidak bersentuhan langsung dengan masyarakat desa sehingga masyarakat desapun banyak yang tidak mengetahui adanya kebijakan siskeudes ini.

Berdasarkan pemaparan di atas, dapat dilihat bahwa implementasi kebijakan siskeudes di Desa Cipeundeuy secara umum sudah berjalan namun msih memilik banyak kendala, bahkan dilaksanakan oleh orang lain. Maka dari agar pelaksanaan kebijakan siskeudes ini dapat berjalan dengan optimal perlu diadakan beberapa perbaikan khususnya dalam pemenuhan dan peningkatan kualitas sumber daya manusia khusunya yang berkaitan dengan siskeudes. Siskeudes itu sendiri sangat penting karena akan mempengaruhi pembangunan yang akan datang di Desa Cipeundeuy. 


\section{Simpulan}

Berdasarkan hasil penelitian dan temuan-temuan di lapangan, maka peyimpulan akhir tentang implementasi kebijakan penggunaan Sistem Keuangan Desa (SISKEUDES) di Desa Cipeundeuy secara umum sudah berjalan walaupun belum optimal, dilihat dari berjalannya siskeudes meskipun ada beberapa hal yang masih perlu diperbaiki seperti hal- hal sebagai berikut. Pertama, sumber daya manusia yang ada dalam pelaksanaan kebijakan siskeudes ini secara kualitas sangat kurang, karena kurangnya minat untuk mempelajari siskeudes ini. Kurangnya keinginan untuk memahami dan menguasai siskeudes ini menyebabkan sumber daya manusia cenderung malas dan tidak berkembang dari segi kemampuan. Kedua, kurangnya fasilitas atau sarana dan prasarana dalam hal ini belum tersedianya jaringan internet yang memadai untuk melaksanakan kebijakan siskeudes ini, sedangkan kebijakan siskeudes ini kebijakan berbasis komputerisasi dan memerlukan jaringan internet karena berbasis online. Ketiga, kurangnya komunikasi yang dilakukan oleh perangkat desa terutama para pelaksana kebijakan siskeudes ini. Dalam komunikasi yang dilakukan oleh kepala desa dengan aparatur desa khususnya sekretaris desa belum berjalan dengan lancar karena kepala desa yang jarang masuk kantor desa.

\section{Referensi}

Abiding, S.Z. (2012). Kebijakan Publik. Jakarta: Salemba Humanika.

Agustino, L. (2014). Dasar-Dasar Kebijakan Publik. Bandung: Alfabeta.

Amalya, T. (2018). Determinants of Village Financial Management and Its Implication toward

Amin, I. (2008). Pokok-Pokok Administrasi Publik Dan Implementasinya. Bandung: Refika Aditama.

Anggara, S. (2012). Ilmu Administrasi Negara. Bandung: Pustaka Setia.

Anggara, S. (2014). Kebijakan Publik. Bandung: Pustaka Setia.

Astuti, T. P., \& Yulianto. (2016). Good Governance Pengelolaan Keuangan Desa Menyongsong Berlakunya Undang-Undang No. 6 Tahun 2014, 1(6), 1-14.

Kusuma, D.R. (2016). Studi Analisis Kebijakan. Bandung: Pustaka Setia.

Handayati, P. (2018). Developing Software for Village Financial Management Through the Implementation of Law No. 6 Year 2014 in the Direction of Good Village Governance.

Hill, M. (2002). Implementing Public Policy. London: SAGE.

Mahsun, M., Sulistyowati, F., \& Purwanugraha, H. A. (2006). Akuntansi Sektor Publik (1 ed.). Yogyakarta: BPFE.

Maksudi, B. (2017). Dasar-Dasar Administrasi Publik. Depok: Raja Grafindo Persada.

Moleong, L. (2011). Metode Penelitian Kualitatif. Bandung: Remaja Rosdakarya.

Mulyadi, D. (2016). Studi Kebijakan Publik dan Pelayanan Publik. Bandung: CV Alfabeta.

Nugroho, R. (2014). Public Policy. Jakarta: Elex Media Komputindo.

Pasolong, H. (2014). Administrasi Publik. Bandung: Alfabeta. 
Purba, R. (2017). Capacity Apparatus Improvement in Managing Economics and Finance towards Independent Village.

Rathod, P.B. (2010). Contemporary Public Administration. India: ABD.

Silalahi, U. (2012). Metode Penelitian Sosial. Bandung: Refika Aditama.

Sugiyono. (2010). Metode Penelitian Administrasi. Bandung: CV Alfabeta.

Suharsaputra, U. (2014). Metode Penelitian Kuantitatif, Kualitatif, dan Tindakan. Bandung: PT Refika Aditama.

Widjaja, H. (2003). Otonomi Desa Merupakan Otonomi yang Asli, Bulat dan Utuh. Jakarta: PT. Raja Grafindo Raja. 